\title{
Rabī Jābir’s Bayrūt Trilogy: Recovering an Obscured Urban History
}

\author{
Ghenwa Hayek
}

MIT

\begin{abstract}
How does a generation without personal memory begin to grapple with its urban past in a nation that has silenced its memories? Moreover, how are symbolic sites of memory recovered and represented by such a generation? Much recent scholarship on post-war Lebanon has studied the memory culture of the decades following the declared end of civil war in 1990. This scholarship deals with the implications of Lebanon's 'amnesiac' political culture on the social and political landscape. In the meantime, Lebanon - and especially Beirut's—urban landscape has been altered beyond recognition by post-war reconstruction, mostly by private real estate holding companies, the most notorious of which is Solidere. In the early 2000s, as Solidere's activity picked up speed, a slew of historical novels about Lebanon and especially Beirut was published in both Arabic and French. In this article, I will focus exclusively on the strategies of urban commemoration in Rabī Jäbir's trilogy. I argue that the genre of historical fiction is used in these novels to re-create the downtown life of Beirut in and around Martyrs' Square from the 19th and early 20th century, a commemoration of a cityscape and an urban lifestyle that its author recreates using the tools of the archive (documents, bibliographies, etc.). This post-memorial fiction-here, I use Marianne Hirsch's definition of postmemory as "second-generation memories of cultural and collective traumas and experience" (22)—attempts to recover Beirut's repressed Ottoman urban history, and to re-write Solidere's narrative of the city center. By intertwining downtown Beirut's past with its present, in a clever back-and-forth palimpsestic act that superimposes the historical city upon the present city—site of capitalist consumption—Jābir's novels map out the old upon the new, and thus refuses the erasure of the ancient city by its newest urbanists. In Jābir's novels, a new, contestatory commemorative narrative of Beirut's history and-more significantly, its present—emerges.
\end{abstract}

Keywords

Rabī' Jābir, Bayrüt Madinat al-'Ālam, Beirut, Lebanon, Lebanese literature, urban literature

By the early 2000s, central Beirut's landscape had changed dramatically from the previous postwar decade. Although slower than initially anticipated, the private development company Solidere's development of the city center had picked up, and Beirut's city center was less devastated than it had been a 
decade earlier. ${ }^{1}$ But as critics like Saree Makdisi bemoaned, reconstruction had come with a hefty price, so that "lost in the development of central Beirut is a sense of history" ("Reconstructing History" 25). For Makdisi and others, this 'authentic' sense of history had been replaced by Solidere's re-imagined history, which was seen as "an attempt to short-circuit the historical experience and the memory of the war itself" ("Reconstructing History" 25). In effect, Solidere's actions were perhaps the most visible manifestation of a deliberate, politicized, social and cultural amnesia widespread across Lebanese society, which has been discussed by Sune Haugbolle and others. ${ }^{2}$

However, as Yael Zerubavel shows, "remembering and forgetting are thus closely interlinked in the construction of collective memory"; interestingly, then, as memories of Ottoman-era Beirut were being wiped from the urban fabric and collective memory, a new generation of Lebanese writers began to write about Beirut, and Lebanon, during this era (8). The early 2000s saw a growing rise in historical novels set in nineteenth-century Beirut, including the focus of this article, Rabī Jābir's Bayrūt Madinat al-'Alam trilogy. ${ }^{3}$ The uncanny contemporaneity of these novels ${ }^{4}$ suggests an emergent interest in the fictionalization of the history of Lebanon and Beirut. Collectively, they seem to indicate the development of a new genre of contemporary Lebanese historical fiction. Following Raymond Williams, we could describe this as a 'structure of feelings' that "can be related to the evidence of forms and conventions-semantic figures - which, in art and literature, are often among the first indications that such a new structure is forming" (133). For Williams, recognizable changes in literary forms were the indications that a new cultural moment was emerging; in the case of Lebanese fiction, this would suggest a

\footnotetext{
${ }^{1}$ A private real-estate development company with direct ties to former Lebanese primeminister Rafì al-Harīīi, la Societé Libanaise pour la Développement et la Réconstruction—referred to by its acronym Solidere-acquired the rights to develop and manage the reconstruction of central Beirut's business and commercial district, an area of 1.8 million square meters, which had been cordoned off from the rest of the city during the Lebanese civil war (1975-1990). Solidere was controversial from the outset; for more on this see Saree Makdisi, "Laying Claim to Beirut: Urban Narrative and Spatial Identity in the Age of Solidere" and "Beirut, A City Without History?"; as well as Jad Tabet's articles in the volumes Projecting Beirut, Reconstructing Beirut and Memory for the Future. For more details on the actual pace and scope of reconstruction in the 2000s, see Najib Hourani's dissertation "Capitalists in Conflict."

2 See Haugbolle's War and Memory in Lebanon for a general overview of this "infamous amnesia" (192); for more on Solidere's role in this, see miriam cooke, "Beirut Reborn"; see also Jad Tabet's work in Memory for the Future and Saree Makdisi's "Urban Narrative."

${ }^{3}$ All the translations in this article are my own.

${ }^{4}$ This list includes Amin Maalouf's Le Rocher de Tanios, Carole Dagher's Le Couvent de la Lune, and Alexandre Najjar's Le Roman de Beyrouth. While interesting as part of a growing trend of Lebanese Francophone historical fiction, these novels are outside the scope of this paper.
} 
correlation between the newfound popularity of the historical novel and the great post-war social and cultural changes in the country. ${ }^{5}$ With discourses of memory as fraught as they are in Lebanon, it is perhaps unsurprising that young writers like Jābir engaged directly and actively with writing — and perhaps, re-writing - the nation and the city's history. Through its discussion of the relations between fiction and historiography, as well as its exploration of the relations between historical and spatial memory, Jābir's trilogy calls the creation and production of historical narratives into question, and raises a new set of concerns about individual and collective belonging to the city and the nation.

\section{Placing the Self in the City}

For human geographers, an individual's 'sense of place' is deeply connected to processes of making emotional and social meaning from relations to specific locations (Dictionary of Human Geography 732). This is connected not only to an individual's well-being, but also to that individual's ability to situate him or herself within the social sphere. In his extremely influential The Image of the City, Kevin Lynch describes this as 'cognitive mapping':

In the process of way finding, the strategic link is the environmental image, the generalized mental picture of the exterior physical world that is held by an individual. This image is the product both of immediate sensation and of the memory of past experience, and it is used to interpret information and to guide action. The need to recognize and pattern our surroundings is so crucial, and has such long roots in the past, that this image has wide practical and emotional importance to the individual ([my italics] 4).

It is significant that Lynch connects successful mapping with the immediate present as well as with memory, the implication being that individuals without access to memory are unable to accurately situate themselves in their environments. This is noteworthy because, in addition to its crucial role in the development of the individual's relation to urban space, the recognizability of an urban landscape is also a social matter, since "a vivid and integrated physical

\footnotetext{
5 The rapid change of the political situation after 2005 seems to have hindered the development of this emergence; in fact, Jābir has abandoned his original plan to create a seven-volume epic series, and has moved on to other genres, including science fiction, and other themes, including the emigrant experience in North America and Europe.
} 
setting, capable of producing a sharp image [...] can furnish the raw material for the symbols and collective memories of group communication" (4). ${ }^{6}$

While earlier generations of Lebanese could situate themselves with respect to Beirut's center through personal recollection, which also mediated collective memory, the younger generation, lacking both memory and immediate perception, simply cannot. Architect Robert Saliba's work on cross-generational mental maps of post-war downtown Beirut shows the clear gaps between each generation's ability to draw the urban space and their connection to the city. The generation that was aged 36-45 in 1991 drew more elaborate mental maps of the city; Saliba found that they were the ones most invested in rebuilding the downtown area as it had been, since "they had greatly interacted with the city center during the 1960s and the 1970s, and the city center formed an integral part of their mindscape"; in short, their personal memories of the space motivated their desires to see it rebuilt as it had been.

In contrast, the generation born immediately before or during 1975 (to which Jābir belongs) is in a curious, in-between predicament. These young people have no recollection of the city center as it was before. ${ }^{7}$ But they also seem to understand that an inability to cognitively map their urban history is problematic, and is hampered by Beirut's controversial reconstruction, which has re-designed the urban space. ${ }^{8}$

What Jābir's novels set out to do is to construct the map of downtown Beirut for the new generation. They re-historicize the city space by delving into its distant past, and moving forward in time into its contemporary present. If, as miriam cooke suggests and Saree Makdisi implies, one of the projects of Solidere's reconstruction of Beirut was "to tame this lieu de mémoire," which entails that "the traces must be eliminated or made to represent another kind of history," then the Bayrüt trilogy appropriates this practice and rewrites it as its own (417).9 Moreover, by unchaining urban memory from exclusively personal memory, Jābir gives his generation a participatory

\footnotetext{
${ }^{6}$ Lynch's work has impacted other fields. In a short essay entitled "Cognitive Mapping," Frederic Jameson takes the basic premises of Lynch's argument and extrapolates them into the political realm, concluding that "the incapacity to map socially is as crippling to political experience as the analogous incapacity to map spatially is for urban experience" (353).

${ }^{7}$ Ironically, although those over 45 drew the most vivid mental maps of the city, they were not as nostalgic as the earlier generation, Saliba found (3).

${ }^{8}$ Dalia Said Mostafa compares Jābir to Elias Khoury, and writes of both writers' representation of Beirut as imbued with a sense of the city's dialectical history, "between the past and the present $[\ldots]$ not only in the sense that the past might be reflected in the present, but rather in understanding the past and the present as two historical processes which continuously interact with and shape one another." ("Literary Representations", 214)

${ }^{9}$ cooke borrows this term from French historian Pierre Nora's work of the same name.
} 
voice in the articulation of Beirut's past and present; furthermore, by reinserting the historic traces of old Beirut onto the contemporary city, Jābir's trilogy draws a new cognitive map of the city that connects its past to its present, and resituates both the individual and the collective in the city center, and in the national past.

On one level then, these novels attempt to counter the spatial and historical aporia of contemporary Lebanon by recovering the roots of an older Beirut. Yet, as Yael Zerubavel points out, the acts of recovering and re-covering are connected $;{ }^{10}$ in short, as this article proceeds, we must be sensitive to the histories being suppressed as well as to those being recovered. ${ }^{11}$ For example, by telescoping back into the mid-1800s and abruptly discontinuing his sevenvolume historical saga Bayrüt in its third installment, which ends in the late 1800s-i.e., before Lebanon's modern history began—Jābir omits many aspects of Lebanon's troubled recent past, including the Mandate period and the twentieth-century Civil War.

Such omissions raise questions about the relationship between historical memory and fictional commemorations that I will address in the next section. But they also raise a greater set of questions: firstly, how does a generation without personal memory begin to grapple with its urban past in a nation that has silenced its memories? Moreover, how are symbolic sites of memory recovered and represented by such a generation? Lastly, is there any value to such historical representation, or is it always condemned to repeat the practices of other commemorative narratives? These are some of the principle questions that I set out to answer in this article.

\section{Between Memory and History}

In Family Frames, Marianne Hirsch introduces the concept of postmemory to describe a particular sort of memory, "distinguished from memory by

\footnotetext{
${ }^{10}$ In fact, Zerubavel's entire book hinges on exploring "the process of recovering and recovering roots" in modern Israeli society (9). Elsewhere in the same work, Zerubavel points out that "by focusing on one aspect of the past [any commemorative narrative] necessarily covers up others that are deemed irrelevant" (8).

${ }^{11}$ Andreas Huyssen gives a provocative reason for this, grounded in the epistemological consequences of a postmodern consciousness: "Once we acknowledge the constitutive gap between reality and its representation in language or image, we must in principle, be open to many different possibilities of representing the real and its memories"; Huyssen modifies this somewhat alarming statement by re-inserting a high modernist critique of quality: "This is not to say that anything goes. The question of quality remains one to be decided case by case" (19).
} 
generational distance and from history by deep personal connection" (22). Hirsch elaborates further, saying that

postmemory characterizes the experience of those who grew up dominated by narratives that preceded their birth, whose own belated stories are evacuated by the stories of the previous generation shaped by traumatic events that can be neither understood nor recreated. (22)

Hirsch herself is particularly interested in the children of Holocaust survivors and their relationship to photographs of that experience, but admits that the term "may usefully describe other second-generation memories of cultural or collective traumatic events and experiences" (22). I believe that Hirsch's notion of postmemory is a useful and productive one for thinking about the position of the young generation of Lebanese writers that emerged in the decade after the Civil War's end. After all, they grew up in the shadow of the collective trauma of war and the narratives of human and urban loss that engendered. Yet, as I have already pointed out, they are separated from personal memories of the city by 'generational distance'; still, they are invested in the urban space by more than a sense of history: they are interested in this space as a heavily symbolic space in their nation's collective imaginary.

However, by far the most interesting thing about how Hirsch's definition of postmemory relates to these second-generation novels is its relation to acts of imaginative creation, such as fiction. For Hirsch, postmemory necessitates a creative intervention in history, since "its connection to its object or source is mediated not through recollection but through an imaginative investment and creation" (22). The relation of Jäbir's novels to the city of Beirut is constructed through an imaginative act that is between history and personal memory, which figuratively and literally blurs the relations between fiction and history.

In Writing History as a Prophet, Elizabeth Wesseling argues that one of the focal ways that the modernist and postmodernist historical novel differs from classical historical fiction is in the former's disruption of traditional narrative patterns through the inclusion of "an additional narrative level, situated between the represented past and the primary narrator" (84). This produces what Wesseling describes as a 'self-reflexive' attitude towards the writing of history, in which a mediating figure-in this case, a young writer-is placed between the events and their narrator. Moreover, this young writer figure often expresses an anxiety about, and unease with, the practice of history. ${ }^{12}$ As a

12 The fact that these novels have both been read as history is compelling: it suggests, perhaps, that this revelatory gesture is not as obvious as Wesseling believes; see Kamāl Șalïbī's Bayrüt 
result, the transmission of historical memory is placed in a mise en abime that allows the narrative to expose the multiple layers of knowledge that undergird history. Jābir's novels complicate the relationship between historical narrative and fiction through exposing the tenuous divide between historical and fictional narrative, what Wesseling describes as the "borderland between fiction and historiography" (120). ${ }^{13}$ Jābir's work "make[s] the production process visible" using "the now familiar ploys of the historian-like character or external narrator who comments upon his own endeavors as he goes along" (Wesseling 119).

Jābir's novel is built around a frame narrative, in which a young novelist called Rabī Jäbir sets out to write the history of a notable Beirut family, the Bārūdiss. ${ }^{14}$ The boundaries between the frame and the story are fluid and collapsible: the trilogy ricochets back and forth between Rabīi and the Bārūdīs. The past, Jäbir's novel suggests, cannot be hermetically separated and contained; the relation between (re-imagined) past and (imagining) present can only be dynamic. Jäbir's narrative strategy produces the 'self-reflexive' attitude towards the writing of history common in contemporary historical fiction that I described above. Not only is the young writer named Rabíi Jābir, just as the author is, he is placed between the novel's historical events and their narrator, the Count de Bustrus. Moreover, this young writer often expresses an anxiety about, and unease with, the practice of writing history.

The trilogy's self-reflexive acknowledgement of the challenge of writing history is complicated from the outset, as it re-writes the paradigm of the author as mediating figure. At the beginning of the trilogy, as he sets out to record the family history, Rabī' receives the help of an older man: the Bārūdīs' last surviving relative, Count de Bustrus. Almost immediately, however, the novel undermines his mission by killing off the Count, leaving Rabī completely flummoxed: "Now, I don't know what to do," Rabī confesses, unsure that the records of the interviews he has conducted with the old Count will be enough to write a novel, and unsure even where to begin now that the Count can no

\footnotetext{
wa-l-zaman. It also possibly gestures to the hunger for history in present-day Lebanon; for more on this, see Saree Makdisi's "Beirut: A City without History?"

13 Wesseling points out that many of the same issues have been discussed in critical work on the relation between history and fiction. While she does not cite them as references explicitly, the work of Hayden White in Tropics of Discourse and Paul Ricoeur in Time and Narrative, vol. 3 is especially relevant to bringing into question the previously clear distinction between historiography and fiction, by calling attention to the discursive nature of historiography and also to the ways in which both deal with the matter of time.

${ }^{14}$ In order to avoid confusion and the awkward use of "the narrator" vs. "the author," in this article, when I refer to Rabīi Jābir the author, I will use "Jābir," or "Rabíi Jābir"; when I refer to the character of Rabīi Jäbir within the text, I will use "Rabì".
} 
longer guide him (16). Yet, he picks a place to start his historical story, and launches into it; from this point, the historical tale of the Bārūdī family becomes his to tell. The historical part of the novel—while intertwined with Rabī's commentary and narrative- - begins with the arrival of the Barūdī family patriarch 'Abduljawād in Beirut from Damascus in the early nineteenth century; it ends with 'Abduljawād's eldest son Shāhin going off to fight in the Crimean war alongside the Ottomans. The second volume takes place after the Egyptian army leaves Beirut, in 1840, and ends in 1865, with Shāhīn's death. The third volume is set between 1865 and the final years of the nineteenth century, and its protagonist is 'Abduljawād's third son, Salīm.

The self-awareness in Jäbir's novels operates not only on the thematic register, but also on a formal one. Bayrüt's playful yet serious tone resonates with Linda Hutcheon's definition of a 'postmodern nostalgia', in which

Nostalgia itself gets both called up, exploited and ironized. This is a complicated (and postmodernly paradoxical) move that is both an ironizing of nostalgia itself, of the very urge to look backward for authenticity, and, at the same moment, a sometimes shameless invoking of the visceral power that attends the fulfillment of that urge. (205)

Jābir's text, an ambitious attempt to write a family saga that encompasses and mirrors Beirut's history, is also self-reflexively, and humorously aware of the pitfalls of such a project in a reconstructed Beirut:

How do you write about a mother living in Beirut before the Egyptian invasion [of 1834] while you're staring at a woman with short orange hair eating pizza with a fork and knife?...your back hurts and you want to see that distant town buried in the obscurity of history, you want to see it [my italics] (190).

The playful juxtaposition of the contemporary, orange-haired woman's incongruous appearance and eating habits with the writer's desire to write about a very different kind of Beiruti woman calls attention to Rabī's awareness of the difficulty of historical writing. And while the urge to capture this history is as yet—and perhaps will remain — unattainable, Rabī's desire for it is as visceral as Hutcheon describes.

Jäbir's novel continues to play with the tensions between writing fiction and writing history, and it simultaneously ironizes and calls attention to the role of the author in historical fiction. For example, in the first volume of Bayrüt, Jābir complains that, "if we were now reading a fictional tale", he could have changed certain events in the narrative (84). Jäbir here uses the plural suffix " $-n \vec{a}$ ", joining the readers as one of them. Rabï does not present himself 
as a writer of fiction, but rather as an historian, rhetorically distancing himself from narrative agency: he is reading history, and not writing a story. But, soon afterwards, Rabî is confronted by his friend Walīd, who wants a happy ending that Rabī cannot provide for him because Rabí is "trying to be as accurate as I can" (228). Walid objects to this, however, and points out that Rabî' is "writing a novel, not history" (228-9). The exchange between both friends playfully-yet obviously - brings into question the role of the writer of historical fiction: is he a historian, with a responsibility to accurately represent the past; or is he a novelist, who can manipulate the story as he wishes? By mobilizing "the now familiar ploys of the historian-like character or external narrator who comments upon his own endeavors as he goes along", Jābir calls attention to the textuality of all historical writing, and blurs the fictional boundaries between fiction and historiography (Wesseling 119).

The blurring of boundaries between fiction and history in Bayrüt occurs not only on the fictional, but also on the metafictional levels; namely through the inclusion of historical documentation in the narrative. ${ }^{15}$ One of the distinctions that Paul Ricoeur makes between historical and fictional texts is the fact that historians have an ethical debt to the past that they must fulfill by taking historical documents into account, whereas novelists do not need to deal with such issues. For Ricoeur, although one may dispute the methodologies or narrative forms of historiography, "the recourse to documents does indicate a dividing line between history and fiction" (3:142). This is one of the features of historiography that allows it to claim that it is the only field capable of reconstructing the past as it actually happened, as "standing-for" the past in Ricoeur's terminology, thereby distinguishing the field from fictional narratives that are imaginary and are not necessarily inflected by a similar indebtedness to an 'actual' historical past. Ricoeur's position, in fact, is dramatized in Bayrüt in the exchange between Walìd and Rabīi discussed above.

Bayrüt's self-aware inclusion of actual historical documentation further calls into question the validity of Riceour's distinction between history and fiction. As Rabī begins to ask another series of rhetorical questions about everyday life in nineteenth-century Beirut, the text turns to the reader; and addresses him directly:

15 This inclusion of historical documents is, in fact, common in contemporary historical fiction. See Wesseling, and also Olga Steimberg de Kaplan, who argues that "in contemporary historical novels, fiction and metafiction combine to varying degrees: the author integrates the recounted history with commentaries on the role of the artist, and of his doubts and objectives as a creator" (13). One such example from contemporary Lebanon is the Francophone writer Alexandre Najjar's Le Roman de Beyrouth, which also features a young narrator attempting to reconstruct the history of a Beirut family. 
What was life like in Beirut in those faraway days? How did its people live, and who were they? The reader does not need to go searching in books to find the answers. The following list of books (and a handful of manuscripts) set down here can be ignored, can be overlooked, and not one thing will change in 'Abduljawād Aḥmad al-Barūdī’s life, which is gone (39-40).

Once more, questions about the lifestyles of people in the past, of being able to understand them prey upon Rabi's mind, and he assumes, also upon the reader's. As Elizabeth Wesseling argues, "self-reflexive historical fiction detracts from the claim to objectivity, but it still grants the possibility of authentic historical knowledge the benefit of a doubt" (119). The text, in fact, follows this quote with an eight-page detailed annotated bibliography containing memoirs, travel narratives, history books, missionaries' journals, and letters, with mention of their places and dates of publication. ${ }^{16}$ Ricoeur's history, it seems, has invaded Jābir's fiction.

Jäbir's novel suggests that, although history and fiction may not blend, their coexistence is nonetheless necessary, and the text can neither privilege nor silence one at the expense of the other. The two sentences beginning "The reader" and "The following" respectively seem, upon multiple readings, to be juxtaposed, and not to follow one after the other in any sort of sequence. They are the borderline at which the fictional and metafictional parts of the novel intersect. The first sentence, coming after the series of questions about life in the past, at first appears to question the possibility of historical knowledge; it is followed, however, by the apparent implication that the reader's questions have an answer, and that this answer will be furnished by the novel. However, that expectation is almost immediately undermined: not only is the reader told that the narrator will not answer the question, but he is also told that the next eight pages of text are actually irrelevant to the plot.

Jābir's inclusion of the bibliography lays bare the historian's tools - not only to augment his authority, but also to challenge readers' complacency and highlight the critical role played by the historical novelist in translating the raw material of history into story. Rabî issues a challenge to the reader (whom he has already directly addressed as "you") who is merely seeking narrative details, how the plot will unfold, by admitting that the next pages have nothing to do with the story of 'Abduljawād's life, but that he has included them anyway. The academic historical documents Rabí anchors into the text (they are described in Arabic as "muthabbatah", i.e., placed in a fixed spot) are, firstly, proof that documents about the everyday lives of Beirut's nineteenth-century

${ }^{16}$ The annotated bibliography is genuine, in that the texts and manuscripts mentioned in it exist. 
inhabitants exist - that history, in fact, has not been completely erased-and that these documents are available to whomever is willing to make the effort to find them. On one hand, then, Jäbir's act exposes an archive of Beirut's history; he makes it visible. ${ }^{17}$ If there is indeed "no political power without control of the archive and of memory," and one of the primary qualities of the archive is its "to shelter itself, and sheltered, to conceal itself," as Jacques Derrida explains in Archive Fever, then Rabï's act reclaims power, by exposing Beirut's deliberately forgotten, archived memory (3-4). ${ }^{18}$

In addition to being an act of reclaiming power by exposing the bibliographic archive, Jābir's decision to include the bibliography "as is" also underscores the role of the writer in creating commemorative narrative. Jäbir exposes how, without his intervention as historical writer, flawed and anxious though he may be, the act of transforming this material into story could not happen. In this way, Jābir underscores the importance of historical fiction as a participant in the formation of collective memory; because he is the one who transforms the raw material of the archive into commemorative text, Jābir sketches out a role for himself in the dialogue over Beirut's memory.

While Bayrüt seems to emphasize the writer's singular role in creating collective history, it also insists that, in Beirut, the desire for historical knowledge is a collective one. As I have already pointed out, the novel frequently expresses the challenge of representing the past; however, just as frequently, this challenge is framed as a challenge for a group, not just the individual writer. "'Abduljawād Ahmad al-Bārūdì's 'now' is difficult for us to imagine 'now' in the 21st century" (24), Rabî' writes at one point, emphasizing the distinct difference, and possibly unbridgeable cognitive gap, between the "nows" of the multiple presents of the imagined community of the contemporary writer and his readers, whom he refers to using the first person plural suffix "-n $\vec{a}$ " and the present of the first volume's nineteenth-century protagonist. This quote reveals a sense of shared contemporaneity between readers and the narrator; both are, at least right now, in the 21 st century, and both are separated temporally from the novel's events. It is hard for all of "us" to imagine the Beirut that al-Bārūdi saw in the 1820s. Rabī's anxiety also resurfaces later on in the text, again intruding upon the Bārūdi clan's story. Rabīi asks himself and all his readers a few pages later "[c]an we imagine the lives of our ancestors in that long-ago,

17 Writing of the art world in the early 2000s, Hal Foster describes the resurgence of an archival impulse in contemporary art, through which "artists seek to make historical information, often lost or displaced, physically present" (4). Foster associates this art with a utopian impulse.

${ }^{18}$ Of course, the question of the archive in Lebanese memory and art is an interesting one; see Saree Makdisi’s "Beirut: A City without History?" for a discussion of the fake archives created by the art collective known as the Atlas Group. 
distant imaginary time?” (63). These moments not only function to recall the periphery between history and fiction, but they also contain an anxiety about knowing the past, an anxiety that can neither be repressed nor suppressed.

But Jābir's rhetorical questions about the possibility of commemoration are not just abstract questions about the challenge of capturing history; they have direct ramifications on the ability of contemporary Beirutis to situate themselves vis-à-vis the historical past of their city. Rabíc asks: "[c]an we today, 165 years after we hosted the British soldiers, imagine Beirut in the 1840s?" (2:123). Here, like in the quotes above, the collective, first-person prefix "nün" is used, indexing the collective challenge of imagining the past. The question is whether anyone in the community can actually achieve an imaginary connection with the past. But this is not just any past, it is the past of our ancestors—aslāfunā —and our city—madinatunā. Additionally, Jābir uses the first-person plural possessive "indan $\bar{a}$ " to forge a link between the city of the past and the inhabitants of his present. Madinatuna belonged to all the inhabitants of nineteenth-century Beirut and the inhabitants of Jābir's contemporary Beirut, the latter sharing with the former the responsibility of "hosting" the invading British army, whose soldiers are described as guests, playfully inverting the common paradigm of invasion, where the invaders represent an imposition. The binary host/guest further underscores the idea that certain people have a binding connection to the city across time, while others are transitory. By linguistically reinforcing the investment of contemporary Beirutis in the past, Jābir's novel creates an imagined community connected temporally, if not spatially, with their urban past.

What is at stake in Jābir's assertion that the city belongs to all, and in Bayrüt's insistence upon temporal and historical continuity between nineteenth-century and twenty-first century cities, becomes clear when read against the spatial practices of Solidere, and other less-known development companies and projects in Beirut. In the early 2000s, as the perceived ownership of the city passed from the people to a corporate oligarchy, a "'deep-rooted middle class struggle[d] to retain Beirut and its 'inherited space' against the capitalist projections of a new global city" (Hanssen 269). ${ }^{19}$ In fact, Saree Makdisi's assertion that what was being "lost in the development of central Beirut is a sense of history" relates the geographical and historical, and undergirds the historical project undertaken in Jäbir's trilogy ("Reconstructing History" 25). In one way, re-historicizing Beirut and its inherited spaces is precisely what these novels are self-consciously doing. It only remains to be seen what kind

19 Throughout "Capitalists in Conflict", Najib Hourani explicitly underlines the fact that all of the disputes over central Beirut's reconstruction were, essentially, disputes between elite groups with considerable capital; it is just the identity and form of capital that is different. 
of city is being fantasized about, and how the spaces of the historical and contemporary Beirut are being imagined.

\section{Bayrūt, Our Global City}

In his seminal Realms of Memory, French historian Pierre Nora makes a distinction between two commemorative sites: lieux de mémoire and milieux de mémoire. Nora argues that lieux de mémoire are the sites in which "memory is crystallized [...] in which a residual sense of continuity remains" (1); examples of these sites include public squares or monuments. Nora contrasts these monumental sites with milieux de mémoire, "settings in which memory is a real part of everyday experience" (2). This definition draws out Nora's important distinction between popular memory, which he seems to suggest is almost organic (he describes memory as "always embedded in living societies", and history, "which is how modern societies organize a past they are condemned to forget because they are driven by change" $(1,3)$. Beirut's city center has often been described as a lieu de mémoire, a (fading) repository of Lebanon's historical memory; ${ }^{20}$ while not denying this, Jābir's Bayrüt also attempts to articulate the city as a milieu de mémoire, a site of popular, collective memory, where the everyday present and everyday past are continually in dialogue with each other, nowhere more so than in the trilogy's mapping of central Beirut's landscape.

Jābir's novel brings Beirut's past into its present through an evocation of spatial relations and spatial memory; specifically, through imagining Beirut as an urban palimpsest. In his work on post-reconciliation Berlin, Andreas Huyssen invites his reader to read the city-space as a palimpsest:

We have come to read cities and buildings as palimpsests of space...An urban imagery in its temporal reach may well put different things in one place: memories of what there was before, imagined alternatives to what there is. The strong marks of the present space merge in the imaginary with traces of the past, erasures, losses and heterotopias (7).

Of course, one cannot bring up the palimpsest, as Sarah Dillon remarks in her book of the same name, without necessarily evoking the key notions of writing, erasure, re-writing and making the traces of the past visible, i.e.,

${ }^{20}$ See, for example, miriam cooke’s "Beirut Reborn." 
producing a genealogical understanding of urban and national history. ${ }^{21}$ Conscious of this, Huyssen nevertheless argues that, without reducing architectural space to text, "literary techniques of reading historically, intertextually, constructively and deconstructively at the same time can be woven into our understanding of urban spaces as lived spaces that shape collective imaginations" (7).

I have already described the metafictional self-awareness of Jābir's text that puts into play the relationship between the historical and present-day narratives of the Bārūdī-Bustrus clan, and those of Rabī as he struggles to find a way to write about them. But Bayrüt also imagines downtown Beirut as a palimpsestic text within its metafictional interplay. For example, present-day Rabí maps the historical city for his friends Walīd and Ibrāhīm by locating it on top of the present city they are walking through on their lunch break:

This street used to be called, in the 19th century, souk al- 'atțirinn [the perfumers' souk]. The street near Parlamento [an Italian restaurant] was the entrance to the Bazirkān. The alleyway near the mosque that now says George Acouri used to be souk al-șarami $[$ [the shoe souk] (67).

While neither Ibrāhīm nor Walīd is particularly interested by this information, each one caught up in his own concerns-Ibrāhīm in a discussion of classical Arabic music, and Walìd in a list of the different cuisines they can eat. As they continue their walk, Rabíss improvised lesson in urban geography triggers Ibrāhimm's memory of working with his father on the calligraphy of a mosque that is currently being rebuilt in the area. Rabî then goes to see the inscription, and finds half of it faded away, illegible. When he returns to the construction site a few months later, he can see the entire inscription, the past being made legible again through restoration. Significantly, it is the act of walking around the city that leads to this palimpsestic — and serendipitous discovery of the past in the everyday life of a city where young lovers embrace, cars honk and hungry friends chatter into cellphones on their lunch breaks (63-67).

But Bayrüt also makes the traces of the city manifest in other ways as well inside the text. One of these is visual; at various moments in the novel, some content is set aside in tables within the text (64-70). Inside the tables Rabī records signs for restaurants ("IL PARLAMENTO", "SCOOZI",

\footnotetext{
${ }^{21}$ Dillon: "the palimpsest is thus an involuted phenomenon where otherwise unrelated texts are involved and entangled, intricately interwoven, interrupting and inhabiting each other" (4). It is also worth remembering that in its first appearance as a metaphor, in Thomas de Quincey's "The Palimpsest of the Human Brain," the palimpsest is intimately linked to memory.
} 
"SEATTLE'S BEST COFFEE") that he has read on the city's walls; plaques indicating street names ("Rue 58 de la Mosquée al-Omari, SECTEUR NAJMEH 11"); the dates of a building's inauguration ("ASTRAL 1929", "OPAL 1931"); and information laid out for the public —in accordance with Lebanese law-by contracting firms charged with the reconstruction of certain sites, which include the project's name, its donors, the chief engineer and his contact information, the contracting company and its address, and the names of the site engineers. Rabî reads all of these signs placed across the downtown cityscape, and Jābir brackets them, rendering visible what is passed by everyday inattentively, both calling attention to these sites, and to the fact that the present cityscape is simultaneously a site of construction and re-construction.

In another process of rendering visible the historic traces of the city within the text, Jābir literally juxtaposes and interchanges the present with the past. As Rabí and his friends walk through the city, the names of the streets they are walking on are placed side-by-side with the bracketed names of these same streets as they were in the nineteenth century. So for example, as they try to find a restaurant to eat in: "I suggest we cross Weygand (that was souk alfashkhah in the 19th century) and go down 'Abdulmalak street (that was 'Abduljawād Street)" (67). This palimpsestic act continues on the next page, but the names are inverted: instead of the old names being bracketed, this time, the new names are: "I find myself before the Manșū 'Assāf mosque (the Sarayy). I light a cigarette, then cross al-fashkhah and make my way down the cotton souk (Foch)" (68). In the following paragraph, the order is inverted once again, "I reach Șiḍiiq mosque (this was the al-Dabbäghah mosque)" (68). The act of bracketing these street names within the text not only implants the historical city beside the current one, it creates a mental map of Beirut that joins present to past without necessarily privileging one over the other.

And while these palimpsestic acts occur within the contemporary part of the narrative, they also - though less frequently-occur within the historical part as well. For example, as the narrative action reaches the point where Shāhīn, 'Abduljawād's son, is standing on a rooftop watching the Egyptian army march into Beirut, the narrative is once more broken by a bracketed note that mentions that these rooftops will be the sites of 'Dunkin' Donuts and Scoozi in the dark and mysterious future" (180). ${ }^{22}$ Bayrüt maps the downtown Beirut area through the everyday lives of its present and past characters. In fact, Bayrüt makes the past city visible textually by a palimpsestic performance.

${ }^{22}$ Ibrāhīm Pāsha led the Egyptian army against the Ottomans and into Syria and Palestine in 1831, but the Egyptian army was forced out in 1840. 
Here, the temporal is interesting: while palimpsests are usually thought of as being remnants of the past in the present, in Jäbir's text, here they reinscribe the past onto the present; in this sense, they are palimpsests-in-reverse, contesting the attempt to make Beirut's future and the past seem "all but indistinguishable, the one a replication of the other" (Makdisi, "Reconstructing History", 25).

This palimpsestic technique of placing the historical city in the contemporary landscape of the novel, however, also underscores a considerable distinction between Beirut-in-the novel's present and Beirut-in-the-novel's past that is manifest in the tension around consumerism. In mapping its way around the old and new city, the novel brings certain pairings into play: of the Italian restaurant Parlamento with the old Bazirkān souk, where 'Abduljawād had his thriving business establishments; of the rooftops of the boys' homes in the nineteenth century with Scoozi (another Italian restaurant, part of a regional chain) and Dunkin' Donuts (180). More examples include the pairing of the al-fashkhah souk with Grand Café (a chain of successful hookah lounges), and Caffe del Centro (yet another Italian restaurant) with the city's old synagogue $(177,185)$. The repetitive substitution of domestic and religious spaces by a different, more homogenized, space of consumption happens throughout Bayrüt. In the twenty-first century, the local is displaced by the global, the ancient souks replaced by international chains, the entire urban economy shifted towards contemporary consumption.

Significantly, the historical part of Jäbir's novel is situated at the moment in Beirut's history when it emerged onto the global stage, as a port city directly enriched by its opening to the global economy. ${ }^{23}$ The depiction of local agency over the changing cityscape, and the incorporation of the local into the urban context in the historical city contrasts with present attempts to exclude the city's lived past. The reminder that Beirut used to be more than a series of chain restaurants and shops through the juxtaposition of the historical sites with the contemporary ones resists the erasure of historical memory from the cityscape that Saree Makdisi accuses Solidere of carrying out:

This new shopping mall [the Solidere masterplan for the old souks] will claim to represent the past and the historical collective memory of the old Beirut souks in what will be a genuinely new space, a space that has been disemboweled literally and cleansed of its past. It will be marketed as a recreation of what was there

\footnotetext{
${ }^{23}$ Writing about the same period when Bayrüt's historical narrative begins, Jens Hanssen also draws the connection between the local and the regional; "during that time (the period between 1830-1840), Beirut changed from a tax farm of the regional overlords to a port-city that served the expanding Mediterranean economy" (264).
} 
before, rather than as something that is entirely novel, something that has no historical depth. It is, rather, part of a much broader process that has from the beginning stripped away the past and laid bare the surface of the city as sheer surface-spectacle—and nothing more ("Reconstructing History" 25).

In his essay, Makdisi is concerned that once the generation with personal memory of Beirut dies, there will no longer be a record of this space that existed and the types of practices carried out there. What Makdisi holds against Solidere is not merely the erasure of history, but the denial that the erasure has even happened, such that "history itself has been fully absorbed in the visual field and it has become the spectacle par excellence" "Beirut: A City Without History?" 212). For Makdisi, Solidere's practices of historical erasure are particularly egregious because they "substitut[e] image for narrative and eras[e] the last traces of that messy, uneven, discordant lived life that the war itself destroyed" ("Beirut: A City without History?" 212). I believe that it is here that Bayrüt redeems itself, and becomes more than the literary counterpart to Solidere's material acts: through undertaking the massively ambitious project of a multi-volume family epic based in Beirut, Bayrūt, is essentially creating a narrative - albeit a selective one — of a large group, and it is re-inserting this narrative of lived life onto the existing surface of reconstructed Beirut.

While Bayrüt insists that the past can neither be completely repressed nor completely effaced, it shares Makdisi's concerns about the future of Beirut's cityscape. The commodification of the contemporary urban space depicted in Bayrüt contrasts with the novel's representation of the city's past, and brings to light anxieties about the city's future. In the novel, it is the latter that is more worrisome than the past. The past, after all, can be reconstructed, as Jäbir does throughout his text, through the transmission of generational tales and the palimpsestic mapping of historical and geographical knowledge. Furthermore, it is a shared past, a past with which all those who claim Beirut as their own can identify. The future, however, is a different matter. As Rabí looks out at the horizon, he notices something in the landscape:

I didn't know at the time that I was looking at the infamous Normandy dump, which would become, in the obscure future, the sea front-with trees and towers — of Solidere's reconstructed city (2: 230).

The quote begins with the same construction ("lam akun a'lam 'inda'idhin"/ I didn't know at the time) used earlier whenever 'Abduljawād or Rabī' or the reader's ignorance of a certain aspect of Beirut's cityscape is brought up. However, what differentiates this ignorance from the earlier one is temporality: this 
is not a space that was, which can be brought into the present through the palimpsestic imagination, but a site that will become something in the future. Although the current dumpsite is projected to become a more pleasant space, the language used to describe this possibly verdant future is anxious. In fact, the metaphor of future obscurity ("al-mustaqbal al-ghämid") contrasts heavily with the idyllic urban landscape projected by Solidere.

Most significant, however, is what has happened to the identity of the city in this quote. No longer Beirut, and no longer belonging to the collective "-nă", the city has lost its most basic identity, and has become Solidere's city. In this context of anxiety over the fate of the city, then, the novel's titleBayrüt Madinat al-'Alam - must be read as a double-sided act of resistance, due to its play on the double meaning of the Arabic word 'älam. In standard Arabic, the word literally means 'world', and so the title could be translated as "Beirut, the City of the World." In many ways, the novel recounts the story of Beirut opening up to the world, going from a small town in the first volume, which begins in 1812, to a proper city by the end of the second, which breaks off at the start of the Crimean war in 1853. The world also flows into Beirut, where even military occupation is transformed into a local success, such as when the Egyptian army brings in fava beans and Beirutis, including the Bārūdī family, add lemon, garlic and oil and make a fortune selling fül to the soldiers, creating a culinary delicacy and several fortunes in the process. Throughout the novel, new objects arrive in Beirut and become appropriated by the local culture, which adapts them to its purpose. Therefore, in one sense, Beirut is the world's city, the port-city of Biläd al-Shàm (the Syrian hinterland), where everything new arrives first (2: 256). Opening up to the world transforms Beirut from a tiny town into a city present on the global map, and the novel celebrates this as ebullience-the word "fawrah," or ebullience, is used often to describe the nineteenth-century city's development $(2: 183,189)$.

But there is also another meaning to the word "älam": the word also means 'people', in the sense of 'the masses'. Read in this way, the title would imply that Beirut is the people's city, a popular space in the full meaning of the word. In fact, in the novel, the nineteenth-century city is often represented as such, the city of the people who live in it and call it their own. While invading armies and foreign dignitaries bring innovative items with them, these are rapidly appropriated and modified to fit local interests by the city's inhabitants. It is the local population that is responsible for the city's expansion, forming committees and pressure groups to lobby the Egyptian or Ottoman governments, and undertaking construction projects such as the port (2:267). Thanks to these local groups acting in the public interest, Beirut becomes a 
site of modernization and urbanization, due to local initiative working with the outside (2:344). ${ }^{24}$ The locals also expand Beirut's limits, and turn it into a city, as they go outside its walls in search of commercial and residential space. In fact, they transform the city (2:344). Yet, that city remains theirs and ours in the present ("madinatuna"). Bayrüt contrasts this episode in Beirut's urbanization with the present-day appropriation of the urban landscape by a forprofit private company owned by a handful of investors. Through the superposition of the old and the new cities, the novel performs an act of resistance to the erasure of the city's popular history.

\section{Becoming Beiruti}

In Jābir's trilogy, the anxiety about beginning to comprehend and appropriate Beirut's imagined past and the collection of ancestral histories converge in one major issue: the process of becoming Beiruti, which itself is intricately connected with issues of belonging. The historical parts of the novels begin when the protagonist seeks refuge in Beirut; in Bayrūt, 'Abduljawād al-Bārūdī escapes from a heinous act committed in Damascus and re-establishes himself successfully in Beirut. Here, the texts channel into a well-established stereotype of the city as haven, which itself is a re-imagination of the earlier notion of the mountain refuge. ${ }^{25}$ The novels' explorations of the subject matter reveal contemporary, competing ideologies of belonging and nationalism, and contesting visions of the function of urban space.

In Bayrüt, the image of refuge is used to emphasize the possibility that, even if one is not born in the city, it is possible to become Beiruti. The novel depicts waves of immigration into the city, and although these new arrivals do not know Beirut at first, they eventually come to know it. But the novel represents the relationship between the immigrants and the city more even more complex than this; in fact, Bayrüt suggests, it is a dialectical one. Through their participation in urban life, these immigrants transform its landscape, and in time, the city transforms them as well, into Beirutis. The phrase "he did not know at the time" is repeated more than once regarding 'Abduljawād's ignorance of the city; but the temporality of the term is significant, because it indicates a learning process: what he may not have known at the time, he eventually learned as his knowledge of the city increased (39), and it is this

${ }^{24}$ See Introduction; Jens Hanssen's Fin de-Siècle Beirut.

${ }^{25}$ This is a historical meme that war novelists such as Etel Adnan, Hanān al-Shaykh and Ghāda as-Sammān exploit to great effect, as they often represent the former refuge as no longer safe. 
knowledge added to the time he lived in Beirut that eventually makes him Beiruti. The implied link is thus made between contemporary young Lebanese who are being introduced to a cityscape that they do not yet know, and the strangers to Beirut who rushed to it in droves in the late nineteenth century, and helped make it into a city: "Quickly they all became sons of Beirut. They didn't turn Beiruti overnight, they became it with the passing of the years" (2: 174). Becoming part of the city is not the result of birthright or coincidence, it is the result of will, just as it is for 'Abduljawād, who "like many others before him became a Beiruti once he decided to live in Beirut and die in it," and as he grew ever more familiar with it (85). As the center of the city entered into private ownership and development in reality, the fiction adjusts, and belonging shifts away from owning land or real estate, to attach to the practice of everyday life in the city.

In Bayrüt, the city is rendered as a welcoming, international, cosmopolitan space that transcends birth or nationalist belonging for a more inclusive, transhistorical geographical loyalty, one willed by the individual and not imposed by outside authority. Belonging is fluid, but strong; 'Abduljawād grows to love the city and to be an influential and integral part of it—becoming a wealthy businessman and eventually a member of the municipal council—through his actions and with his growing knowledge of it. The link between the narrated past and the narrative present in Jabir's text is further effected in the first volume of the novel by the analogy between a present-day reader and the main character of the first volume, not a local but an adopted Beiruti originally from Damascus:

The reader of these words (yes, you) is like 'Abduljawād Aḥmad al-Bārūdi. Neither knows old Beirut: A town of five thousand inhabitants, surrounded by a wall, looking out onto the sea in one direction and onto fields, hills and plains in the other three. (39)

The reader is redeemed because, just as Bārūdī learnt about the city and eventually became Beiruti, the reader can also learn to know and belong to the 'old' city through the novel's textual mediation. In Jābir's novels, the repeated assertion that belonging to a space is about the acquisition of knowledge relating to its history and geography (and so not just about ownership or state acknowledgement) also, with repetition, builds up into a rejection of the contemporary marginalization of Beirut's current residents from everyday practices in the city. In these novels, a metaphorical cartography is made manifest and literal through Beirut's urban landscape as pressing questions of Lebanon's identity and character were entering into a new phase. 


\section{Works Cited}

Cooke, Miriam "Beirut Reborn: The Political Aesthetics of Auto-Destruction." The Yale Journal of Criticism 15.2 (2002): 393-424. JSTOR. Web. 19 Jan. 2010.

Dagher, Carole. Le Couvent de La Lune. Paris: Plon, 2002. Print.

Derrida, Jacques. Archive Fever: A Freudian Impression. Religion and Postmodernism. Chicago: University of Chicago Press, 1996. Print.

De Quincey, Thomas. "The Palimpsest of the Human Brain." 1845. Quotidiana. Ed. Patrick Madden. 1 Dec 2006. Web. 28 Aug. 2010. <http://essays.quotidiana.org/dequincey/ palimpsest_of_the_human_brain/>.

Dillon, Sarah. The Palimpsest: Literature, Criticism, Theory. London; New York: Continuum, 2007. Print.

Foster, Hal. "An Archival Impulse.” October 110. Fall 2004 (2004): 3-22. JSTOR. Web. 23 Feb. 2010.

Hanssen, Jens. Fin De Siècle Beirut: The Making of an Ottoman Provincial Capital. Oxford Historical Monographs. Oxford: Clarendon Press, 2005. Print.

Haugbolle, Sune, War and Memory in Lebanon. New York: Cambridge University Press, 2010. Print.

Hirsch, Marianne. Family Frames: Photography, Narrative, and Postmemory. Cambridge, Mass.: Harvard University Press, 1997. Print.

Hourani, Najib. "Capitalists in Conflict: A Political Economy of the Life, Death and Rebirth of Beirut “. Diss. New York University, 2005.

Hutcheon, Linda. "Irony, Nostalgia, and the Postmodern." Studies in Comparative Literature 30 (2000): 189-207. Print.

Huyssen, Andreas. Present Pasts: Urban Palimpsests and the Politics of Memory. Cultural Memory in the Present. Stanford, Calif.: Stanford University Press, 2003. Print.

Jābir, Rabīi . Bayrūt Madīnat al-'Alam. 1st ed. 3 vols. Casablanca: al-Markaz al-Thaqāfì al-'Arabi, 2003-2006. Print.

Jameson, Frederic. "Cognitive Mapping", Marxism and the Interpretation of Culture. Ed. Nelson, Cary and Grossberg, Lawrence. Communications and Culture. Basingstoke: Macmillan Education, 1988. 347-357. Print.

Johnston, R. J., ed. The Dictionary of Human Geography. 4th ed. Oxford, UK; Malden, Mass.: Blackwell Publishers, 2000. Print.

Lynch, Kevin. The Image of the City. Cambridge, Mass.: Technology Press, 1960. Print.

Maalouf, Amin, Le Rocher de Tanios. Paris: Le Livre de Poche, 1996. Print.

Makdisi, Saree. "Reconstructing History in Central Beirut." Middle East Report 203 (1997): 5-11. JSTOR. Web. 26 Feb. 2007.

_. "Laying Claim to Beirut: Urban Narrative and Spatial Identity in the Age of Solidere." Critical Inquiry 23 (3). Front Lines/Border Posts. Spring 1997. 660-705. JSTOR. Web. 26 Feb. 2007.

- "Beirut: A City without History?" Memory and Violence in the Middle East and North Africa. Ed. Makdisi, Ussama Samir and Silverstein, Paul. Bloomington: Indiana University Press, 2006. 201-14. Print.

Najjar, Alexandre. Le Roman De Beyrouth. Paris: Plon, 2005. Print.

Nora, Pierre, and Kritzman, Lawrence D. Realms of Memory: Rethinking the French Past. European Perspectives. English-language ed. 3 vols. New York:Columbia University Press, 1996. Print.

Ricoeur, Paul. Time and Narrative. Vol. 3. Chicago; London: University of Chicago Press, 1988. Print. 
Saliba, Robert. "Deconstructing Beirut's Reconstruction." Coming to Terms with the Colonial Heritage. Amman. April 19 2000. Lecture. Web. <http://www.csbe.org/saliba/essay6. htm>. 30 Mar. 2010.

Șalībī, Kamāl. Bayrüt wa-l-Zamān; Qirä’a fi-Riwāyat Rabī Jäbir al-Thulāthiyya Bayrüt Madìnat al-Älam. Beirut: Dar Nilsun, 2009. Print.

Said Mostafa, Dalia, "Literary Representations of Trauma, Memory, and Identity in the Novels of Elias Khoury and Rabī Jābir." Journal of Arabic Literature 40 (2009) 208-236. Print.

Spargo, Tamsin. Reading the Past: Literature and History. Basingstoke: Macmillan, 2000. Print.

Steimberg de Kaplan, Olga. "Le Roman Historique: Interpretation et Connaissance." Genres as Repositories of Cultural Memory. Leiden 1997. Amsterdam; Atlanta, GA: Rodopi, 2000. 7-17. Print.

Wesseling, Elisabeth. Writing History as a Prophet: Postmodernist Innovations of the Historical Novel. Amsterdam; Philadelphia: J. Benjamin Pub. Co., 1991. Print.

White, Hayden. Tropics of Discourse: Essays in Cultural Criticism. Baltimore; London: John Hopkins University Press, 1978. Print.

Williams, Raymond, Marxism and Literature. Oxford: Oxford University Press, 1977. Print.

Zerubavel, Yael. Recovered Roots: Collective Memory and the Making of Israeli National Tradition. Chicago: University of Chicago Press, 1995. Print. 